\title{
Some theoretical perspectives of co-creation and co- production of value by customers
}

\author{
Author: \\ Nic S. Terblanche ${ }^{1}$ \\ Affiliation: \\ ${ }^{1}$ Department of Business \\ Management, Stellenbosch \\ University, South Africa \\ Correspondence to: \\ Nic Terblanche \\ Email: \\ nst@sun.ac.za \\ Postal address: \\ Private Bag X1, Matieland \\ 7602 , South Africa \\ Dates: \\ Received: 25 Oct. 2013 \\ Accepted: 11 Feb. 2014 \\ Published: 15 May 2014 \\ How to cite this article: \\ Terblanche, N.S., 2014, \\ 'Some theoretical \\ perspectives of co-creation \\ and co-production of \\ value by customers', Acta \\ Commercii 14(2), Art. \#237, \\ 8 pages. http://dx.doi. \\ org/10.4102/ac.v14i2.237

\section{Copyright:} \\ (C) 2014. The Authors. \\ Licensee: AOSIS \\ OpenJournals. This work \\ is licensed under the \\ Creative Commons \\ Attribution License.
}

Orientation: The initial introduction of co-production and co-creation in the marketing literature in all likelihood was in 1986 when Kotler used the term 'prosumer' (initially coined by Toffler in 1980) to refer to customers who produce some of the goods and services they consume. Kotler also noted an increase in people's propensity to act as a prosumer of some of the goods and services they bought.

Motivation for the study: No real attention was paid to the concepts of co-production and co-creation by marketing academics after the initial introduction of the concepts. Only after the year 2000 did co-production and co-creation begin to receive the attention of marketing academics, with a substantial increase in publications over the past few years.

Contribution/value-add: The objective of this article was to present an overview of the origin and development of co-creation and co-production in marketing, to draw a distinction between the two concepts and to address the implications of these concepts for various decision areas in marketing.

\section{The re-emergence of the participating consumer}

Marketing has evolved over the years from a pre-industrial state of one-to-one economic exchanges between a producer and consumer as firms have had to adapt their marketing focus to changing environmental factors. Originally, exchange was a one-to-one trading of skills. As firms increasingly became larger and more complex, focus on the customer as a direct trade partner largely disappeared and the services-for-services nature of exchange was masked. Focus shifted to the tangible good, the transaction and embedded value. Today however, marketing strives to resemble its initial state of a one-to-one economic exchange (Vargo \& Lusch 2004). The customer's role in the industrial system has transformed from being isolated, unaware and passive to connected, informed and active (Terblanche 2005). Marketing literature has attempted to capture this shift in the role of the customer in an economic exchange and initially referred to it as customer participation.

Before customer participation was accepted as customer value co-creation or value co-production in marketing literature at the beginning of the 21st century, the concept of customer participation first appeared in the literature in a paper by Lovelock and Young (1979). This documented the productivity gains a firm could realise by allowing its customers to participate in consumption and thus assume some of the firm's work. Toffler (1980) contributed the concept of the 'prosumer', defined as a customer who produces some of the goods and services they consume, and he noted an increase in people's propensity to act as a prosumer of some of the goods and services they bought (Kotler 1986). After that, the concept of customer participation appeared increasingly often in the literature. Initially, literature focused on the economic implications of customer participation (Bendapudi \& Leone 2003). In addition to Lovelock and Young's contribution of the firm's productivity gains from allowing customer participation, a number of other authors noted the importance of customer participation for productivity gains (Bowers, Martin \& Luker 1990; Fitzsimmons 1985; Mills, Chase \& Marguiles 1983). Literature also addressed the customer as a partial employee in the firm (Bowers et al. 1990; Kelley, Donelly \& Skinner 1990; Mills, Chase \& Marguiles 1983; Mills \& Morris 1986), customer participation's effect on service quality (Dabholkar 1990; Goodwin 1988; Lengnick-Hall 1996), customer participation's effect on their own satisfaction (Czepiel 1990; Van Raaij \& Pruyn 1998), using customer participation to segment customers (Bateson 1985) and the changing role of the customer (Firat, Dholakia \& Venkatesh 1995; Firat \& Venkatesh 1993; 1995; Prahalad \& Ramaswamy 2000; Wind \& Rangaswamy 2000).

Bitner et al. (1997) identified three levels of customer participation in service delivery: a low level of participation only requires the customer's presence in service delivery, a moderate level of participation requires customer inputs in order for the service to be delivered and a high level 
of participation involves the customer as a co-producer of the product or service. Researchers started to adopt the terms 'co-creation' and 'co-production' to describe customer participation in the exchange.

\section{The shift to a service-dominant logic}

Traditionally, marketing adopted a goods-dominant (G-D) logic from economics, which focused on operand resources, the physical good, the transaction and value that was embedded in the physical good and transferred to the customer during the exchange. Vargo and Lusch (2004) argued that marketing thought was converging in such a way that new-dominant logic, a service-dominant (S-D) logic, has emerged. S-D logic is essentially customer centric and market driven. Value is offered to customers in the form of a value proposition. The customer must participate in the exchange for value to be created. A distinction was made between value-in-exchange, which was the focus of G-D logic, and value-in-use, the focus of S-D logic.

S-D logic states that value is jointly created by the customer and the supplier, and not transferred during the transaction (Vargo, Maglio \& Akaka 2008). The supplier presents the value proposition to the customer, and when the customer accepts the value proposition and participates in creating value it becomes value-in-use (Ballantyne \& Varey 2006). S-D logic includes the transaction of both tangible products and intangible services. Transactions involving tangible products use the product as a vehicle on which operant resources can be delivered (Ballantyne \& Varey 2006; Vargo et al. 2008). S-D logic has several underlying principles that differentiate it from the traditional G-D logic. The underlying principles of S-D logic can be found in Table 1.

Of these principles, there are three major underlying principles that are important to the co-creation dimension of S-D logic. Firstly, and most importantly, 'the customer is always the co-creator of value' (Vargo \& Lusch 2008). This means that the creation of value is an interactional process that requires the active participation of both the customer and the supplier. Secondly, 'the enterprise cannot deliver value, but only offer value propositions' (Vargo \& Lusch 2008). This means that firms can offer resources to the customer but value is only created once the customer uses the resources. Value is not simply delivered to the customer through the exchange. Thirdly, 'value is always uniquely and phenomenologically determined by the beneficiary' (Vargo \& Lusch 2008), meaning that the individual receiving the benefits of the transaction will determine the value derived from it based on their current experience, previous experience and unique needs.

\section{Defining co-creation and co- production}

In earlier literature, the terms co-creation and co-production were used interchangeably and no finer distinctions were made to separate the concepts. Although they referred to the same thing, customer participation, the term co-creation was used in regard to customer's knowledge input and the interaction between the customer and the firm and coproduction was used in terms of customer participation in new product and service development.

Vargo and Lusch (2004) originally used the terms co-creation and co-production interchangeably. Their initial phrasing of FP7 (see Table 1) was 'the customer is always a co-producer of value'. Consequently, a number of critics pointed out that co-production is more of a G-D term as it implies that something has to be produced or manufactured. It took the focus off the experience. Therefore, Vargo and Lusch revised their definition of co-creation into a further two components. The first part is the co-creation of value. This means that value is not created by the firm and transferred to the customer during the transaction, but rather is jointly created by the customer and the supplier during consumption. The second part of co-creation is co-production. Co-production is the customer's (or any other stakeholder's) participation in the core offering itself. It takes place when there is joint inventiveness, joint production of related products and codesign. FP7 was rephrased to 'the customer is always a cocreator of value' to broaden the scope of the principle.

Etgar (2008) concurred with this distinction between coproduction and co-creation. He noted that co-creation takes place from the customer's initiation with the firm to the final consumption stage, whilst co-production precedes the consumption stage and takes place in the production stage. Co-production is directly related to customisation and encompasses all forms of cooperation between the customer and the supplier (Etgar 2008). Therefore, co-production is a component of co-creation. Other authors have also expressed opinions regarding the distinction between the terms cocreation and co-production. Some authors, such as Payne et al. (2009), still use the terms co-creation and co-production interchangeably. Ballantyne and Varey (2006) argued that cocreation is a completely different concept to co-production and that the two terms are not connected. In their view, co-creation is a collaboration that results in unique value through dialogical interaction, whereas co-production requires known resources and essential capabilities.

TABLE 1: Foundational principles (FP) of service-dominant logic.

\begin{tabular}{ll}
$\begin{array}{l}\text { Foundational } \\
\text { principles }\end{array}$ & Service-dominant logic \\
\hline FP1 & Service is the fundamental basis of exchange \\
FP2 & Indirect exchange masks the fundamental basis of exchange \\
FP3 & $\begin{array}{l}\text { Goods are a distribution mechanism for service provision } \\
\text { FP4 }\end{array}$ \\
Operant resources are the fundamental source of competitive \\
advantage
\end{tabular}

Source: Vargo, S.L. \& Lusch, R.F., 2008, 'Service-dominant logic: Continuing the evolution', Journal of the Academy of Marketing Science 36(1), 1-10 
Ballantyne and Varey also differed in thought from Vargo and Lusch (2004) as they argued that the supply chain is no longer a linear process and that competitors, suppliers and customers co-create within an integrated network wherein they both work together and compete with each other. According to them, if S-D logic is accepted the role of the marketer will be to manage communication and interaction across different media to facilitate key relationships. It will no longer be a situation where firms serve their customers, but rather a situation where the firm and the customer serve each other (Ballantyne \& Varey 2006). Grönroos (2008) distinguished between the concepts of co-production, cocreation and value facilitation. He stated that customers are the value creators. The firm's role is to provide products and services that customers can use in their everyday processes. In this way, the firm is a value facilitator. When the firm provides the customer the opportunity to interact with it in a direct and active way, the firm can influence the customers' perception of quality and together they influence the value created in the customer's processes. In this case, value is cocreated between the customer and the firm. The important view here is that the firm gets the opportunity to be involved in the customer's value creation processes, and not the other way round. Co-production is the customer's involvement the supplier's production processes, not just the interaction in the consumption stage. This is illustrated in Figure 1.

\section{The implications of co-creation and co- production for marketing theory}

The concepts of value co-creation and value co-production are receiving more and more attention. To date, these concepts have been viewed from many different perspectives, and research has investigated co-creation within different marketing domains. This section reviews the significant work on co-creation and co-production to date and the various implications for marketing.

\section{Three important components of co-creation}

Co-creation is an experience-oriented concept which focuses on the interaction between the firm and the customer (Ramaswamy \& Gouillart 2010). Therefore, co-creation has three important aspects to it, namely the customer, the firm and the interaction between the customer and the firm.

\section{Customer co-creation}

Customers are now informed, connected and empowered on a scale larger than ever before; due to Internet technologies they have access to new tools that enable them to co-create with firms (Ramaswamy 2008). Customer empowerment has resulted in a change in the roles adopted by customers during their purchase experience and has given rise to customer cocreation. Co-creation has been addressed from the customer's perspective in terms of the stages they go through when participating, what motivates them to participate, their roles in co-creation and their participation styles.

Different purchase contexts require different amounts of customer involvement, determining the input contributed by the customer and the firm. Customers can be involved in marketing and sales, customer service, the deployment of new products and as partial employees (Zhang \& Chen 2008). Customers may also be included via self-service technologies, through unique experiences with the firm, by participating in a process to solve their problems and by cocreating the final product (Payne, Storbacka \& Frow 2008). The level of customer participation in co-creation varies depending on the knowledge and skills of the customer as well as the complexity of the task at hand. The level of customer participation also influences the outputs of the transaction and determines whether there will be an ongoing relationship between the customer and the firm (Andreu, Sanchez \& Mele 2010).

Etgar (2008) investigated the basic links between coproduction and customisation and presented co-production as a process consisting of five distinct stages that customers are involved in. Etgar's framework maps the customer coproduction process from conditions preceding the customer's participation, to the motivations of participation, to the customer's cost-benefit evaluation of whether to participate, to the physical act of participating and finally to the result and evaluation of their participation. The model can be used as an analytical tool for researchers or as a segmentation tool for managers to segment customers according to their tendencies to engage in co-production.

A conceptual framework of the motivational mechanisms of customers' propensity to engage in co-creation shows that global values as well as domain-specific values affect customer attitudes, self-efficacy and ongoing behaviour which shape their intentions to engage in co-creation in the future (Xie, Bagozzi \& Troye 2008). The level of customer participation in co-creation depends on the customer's technical ability, the information they possess and the costs of participation (Gurau 2009).

When using electronic services, customers co-produce knowledge. Customers play a variety of roles in knowledge co-production that influence different innovations tasks. Knowledge co-produced by customers has the ability to improve different innovation tasks substantially during

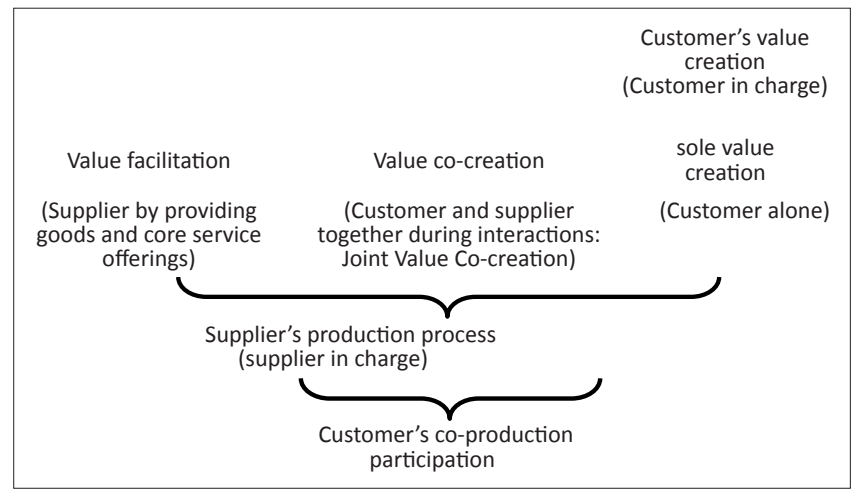

Source: Grönroos, C., 2008, 'Service logic revisited: Who creates value? And who co-creates?' European Business Review 20(4), 298-314

FIGURE 1: Co-creation and co-production from a value-in-use perspective. 
innovation activities. Customers have three specific roles in knowledge co-production that have a substantial impact on different innovation tasks: passive user, active informer and bidirectional creator (Blazevic \& Lievens 2008).

Customers have been documented as resource integrators such that six different styles of customer co-creation arise that are linked to different co-creation outcomes. The six styles of co-creation are: team manager, isolate controller, partner, spiritualist, adaptive realist and passive complaint (McCollKennedy et al. 2009). Customers who exhibit an adaptive realist style of co-creation tend to have a high-quality life, whilst in contrast customers who exhibit passive complaint or isolate controller styles tend to have a low quality of life (McColl-Kennedy et al. 2009).

In the context of new product development in virtual cocreation projects, the influence of customers' personalities, motivations and expectations on their decisions to participate in virtual co-creation projects has been researched. It was found that customers with different types of personalities have different motivations to engage in co-creation. Four different kinds of customers emerged as a result: reward oriented, need driven, curiosity driven and intrinsically interested (Füller 2010).

The implications of customer co-creation for marketing are that the success of the co-creation experience depends on the customer's knowledge, skills, technical ability and the complexity of the task and costs of participation. Furthermore, it is evident that customers assume different roles and cocreation styles depending on their personality that result in different outcomes, and even define their quality of life.

\section{Firm co-creation}

Firms are using the engagement experiences between customers and firm stakeholders to create value. Interactions between people everywhere in the firm's system is the new locus of value creation; therefore, firms must be structured to function around these interactions to find opportunities to co-create with customers (Ramaswamy 2009). The firm provides services and goods that render service to facilitate customer co-creation of value (Ballantyne \& Varey 2006). Firm co-creation has been addressed in the literature in terms of creating environments that facilitate co-creation and the role of the employee in co-creation.

Facilitating the co-creation experience with customers requires the firm to design better experiences for employees as well (Ramaswamy \& Gouillart 2010). To do this, firms need to focus on creating environments that facilitate co-creation. Firms need to create a platform for employees to interact with customers, such as having well-trained employees, information infrastructure and resources in place (Prahalad \& Ramaswamy 2004).

Employees have different responsibilities when facilitating co-creation. Employees must adapt customer skills and capabilities when they co-create value, they need to collect and use customer input when developing products and also share this input with other relevant stakeholders, they must use customer input to provide personalised service and the firm must be flexible when co-creating and implementing decisions that were reached by both the customer and employees during their interaction (Gurau 2009).

There are four basic underlying principles firms need to adhere to for successful co-creation. There needs to be value for the employees in order for them to participate. Focus must be on the experience of all stakeholders not just the customers. Employees must be able to communicate directly with one another and firms must have a foundation enabling sharing and interaction between stakeholders (Ramaswamy \& Gouillart 2010).

In a co-creative business, other stakeholders, including customers, employees and distributors, participate in management decision-making on practices such as personnel management, marketing and product design. These firms achieve considerable success in increasing revenue and lowering costs. The French parcel post and banking company LaPoste is an example of how a firm is able to use a co-creative approach to improve customer satisfaction, employee morale and significant growth in the company's operations (Ramaswamy \& Gouillart 2010).

Guo and $\mathrm{Ng}$ (2010) investigated the effects of interpersonal relationships on service performance. In outcome-based equipment provision services, the service provider often relies on the customer's operand and operant resources to produce service outcomes. Successful service co-production is accomplished through the cooperation between individual employees, especially those who span the boundaries of the provider and the client organisations.

The implications of firm co-creation in marketing is that firms need to design platforms from which employees can access the necessary resources and assume the necessary responsibilities to engage in co-creation with customers. Firms must ensure that employees attain value from cocreating and that there is open communication enabling sharing and interaction between all the stakeholders of the firm.

\section{The co-creation interaction}

If the concept of interaction is not fully understood, the concept of value of co-creation cannot be understood (Grönroos 2011). To highlight the critical importance of each interaction between the customer and the firm, Prahalad and Ramaswamy (2004) developed the DART model to illustrate how dialogue, access, transparency and risk benefit comparison lead to effective co-creation between firms and customers.

A framework for understanding and managing co-creation has been developed which maps customer value-creating 
processes, firm value-creating processes and encounter processes and details how these three components can be used to manage co-creation. This process-based framework provides a structure for customer involvement that takes account of key foundational propositions of S-D logic and places the customer explicitly at the same level of importance as the company (Payne et al. 2008). This framework has been empirically tested and supported in the furniture industry (Andreu et al. 2010).

A typology of different service contexts was developed which maps customer input against supplier input, from which four different service contexts emerge: a discrete service context with low input from both, a relational service context with high input from both, a customer-dominant service context with low supplier input and high customer input and a supplier-dominant service context with low customer input and high supplier input. Co-creation is seen as a two dimensional construct wherein customer participation can be seen either as an information resource or as a co-developer (Zhuang 2010).

Important dimensions of co-creation have also been identified. Firstly, co-creation is a dynamic and continually changing process. It involves interaction between the customer, the firm and significant stakeholders in their various networks. These interactions are dynamic and will change along with changes in the market, and therefore so will the meaning of value. Secondly, because the customer co-creates the end product, they will feel partially responsible for the outcome. The customer and the firm engage in dialogue because of mutual trust and are able to co-create through integrity and shared risk. Thirdly, because of the customer's involvement in the creation of the end product, it should satisfy their needs better. Lastly, as the firm interacts with the customer it gathers knowledge about the customer's needs and can use this knowledge to offer better value propositions to the customer in the future (Randall, Gravier \& Prybutok 2011).

In the development of a valid and reliable scale to measure cocreation, it was found that co-creation is a multidimensional construct consisting of two primary dimensions, namely customer participation and citizenship behaviour. Customer participation behaviour entails information seeking and sharing, responsible behavioir and personal interaction. Citizenship behaviour on the other hand entails a customer's feedback, advocacy, helping and tolerance (Yi \& Gong 2012).

\section{Behavioural outcomes of co-creation}

Co-creation leads to a number of behavioural outcomes. Links were found between co-production and customer loyalty in the financial services sector as well as in the medical services sector. Furthermore, partial support was found for the effect of customer expertise, customer-advisor communication, customer affective commitment and interactional justice on the level of co-production (Auh et al. 2007). In the actual interaction between the customer and supplier where cocreation takes place, it was found that connection is rooted in emotional attachment, which enhances the effect of trust and commitment on future intentions in customers to co-create value (Randall et al. 2011).

Co-creation also leads to certain behavioural outcomes in the domain of service recovery. No purchase transaction, whether it involves a product or a service, can be perfect every single time. It was found that customer participation in recovery efforts after a service failure in self-service technology contexts they are more likely to experience role clarity, perceived value of future co-creation, satisfaction with recovery efforts and future intentions to engage in co-creation (Dong, Evans \& Zou 2008). Further research has extended the study of co-created recovery efforts to non-self-service technology contexts and to service failures where customers did not co-create recovery efforts. Findings show that co-created recovery efforts improve customer evaluations for severe service delays but not for less severe delays and that co-created recovery efforts go beyond affecting satisfaction but also affect repurchase intentions. Co-creation as a recovery strategy was found to work only if customers viewed it positively. An important finding was that customer evaluations did not increase if firms exceeded customer requests; therefore, firms should simply meet customer requests in co-created service recovery situations (Roggeveen, Tsiros \& Grewal 2011).

A conceptual model of co-creation has been developed in the tourism industry where firm support for the customer significantly influences the degree to which the customer co-creates with the firm. In turn, the degree to which the customer is involved in co-creation positively influences customer satisfaction with the firm, customer loyalty and customer spending. Customers who are satisfied with their performance in co-creation tended to spend more with the firm but were less satisfied with the firm overall (Grisseman \& Stokburger-Sauer 2012).

\section{Co-creation from different perspectives}

Researchers have taken a number of different approaches to examine co-creation, including a service science approach, a service logic approach, a social systems approach and approaches from cultural and economic perspectives.

Co-creation has been assessed from a service science perspective in conjunction with an S-D logic perspective, so that the creation of value is the core purpose and central process of the economic exchange and each party in the interaction is viewed as a service system. In contrast to the traditional view of value as defined by output and price, from a service systems perspective mutually beneficial resources are integrated in the exchange to create value. Value is derived and determined when these resources are used in a specific context instead of value resulting as an embedded output of exchange (Vargo et al. 2008).

From cultural and economic perspectives, research into customer co-creation in the context of new digital media 
provides evidence that consumer-producer interactions are an increasingly important source of value creation. Cultural analysis and economic analysis have been identified as potentially useful in the study of co-creation and customer firm interactions. Situated creativity should be interpreted as the analysis of an ongoing co-evolutionary process between economic and cultural dynamics (Potts et al. 2008).

Co-creation (as a management technique) has also been assessed from the perspective of cultural, social and economic politics. Zwick, Bonsu and Darmody (2008) draw on Foucault's notion of government and neo-Marxist theories of labour and value to assess the cultural, social and economic politics of co-creation; they suggest that co-creation is simply a new form of political power and 'argue that the discourse of value co-creation stands for a notion of modern corporate power that is no longer aimed at disciplining consumers and shaping actions according to a given norm, but at working with and through the freedom of the consumer. In short, administering consumption in ways that allow for the continuous emergence and exploitation of creative and valuable forms of consumer labor is the true meaning of the concept of co-creation' (Zwick et al. 2008).

S-D logic's view of value-creation has been questioned and an alternative view put forward on who really creates and co-creates value based on a service logic approach. Service logic assumes that value-in-exchange refers to resources used as a value foundation that are aimed at facilitating customers' fulfillment of value-in-use. Customers are value creators when the value-in-use concept is the foundation of value creation. When the firm adopts service logic, it is able to get involved with its customers' value-generating processes, and the market offering is expanded to including firm-customer interactions. In this way, the supplier can become a co-creator of value with its customers. Drawing on the analysis, 10 concluding service logic propositions were put forward by Grönroos (2008). A further seven statements, including six of the original foundational premises of S-D logic, are reformulated according to service logic to add substance to the concept of co-creation (Grönroos 2011). In essence, the customer is the value creator and it is the firm's responsibility to put foundations in place that will enable it to co-create value with the customer (Grönroos 2008; 2011).

Co-creation has been assessed from the perspective of social systems where it is noted that service exchange and S-D logic are influenced by social forces. Key concepts from roles, reproduction, interaction, positions and social structures and systems theories are used to explain the social systems approach to co-creation. It is proposed that value should be understood as value-in-social-context rather than valuein-use because of the significant influence of social forces on value, and that value is a social construction because value is embedded in social systems (Edvardsson, Tronvoll \& Gruber 2011). The social roles across firms' networks are seen as resources for change as they lead to social norms and present social positions and value-creating relationships. Notable changes in social roles have been taking place in value networks, most significantly the trend of co-production (Akaka \& Chandler 2011).

\section{The managerial implications of co-creation for products and service offerings}

Prahalad and Ramaswamy (2003) argue that co-creation is the next frontier in innovation and competitive advantage. This is because the co-creation interaction between customers and firms has profound implications on what exactly the customer consumes in the end. Because customers participate in value creation, they have a much larger influence over the outcome they experience with the firm. Therefore, co-creation affects the firm's ability to provide personalised service and better customisation so that it can use customer input to develop better value propositions.

Because of the input and feedback the firm collects when interacting with the customer in the value creation process, cocreation allows the firm to provide more personalised service and customised offerings. Co-production in particular is directly linked to the firm's customisation capabilities (Etgar 2008). Co-creation enables firms to include customers in the design of their products. In the context of virtual co-creation it has been found that the co-creation experience significantly impacts the number of contributions by consumers as well as the quality of submitted designs in a virtual new product development project (Füller, Hutter \& Faullant 2011).

Firms can develop and foster a customer community, who they can co-create value with by providing and receiving information to enable product innovation and co-create a consumption experience with customers via the customer community. A case study of a sporting company found that the company's innovative product development strategy provided the catalyst for co-creation of a customer experience. Its marketing actions extended beyond product development and innovation to actively co-create experiences with customers, fostering a sense of community amongst users, facilitating communication within that community, acting on the feedback and continuously developing and maintaining the community relationship (Rowley, Kupiec-Teahan \& Leeming 2007).

The involvement of customers in new product development (NPD) forces firms to rethink their traditional NPD strategies. Firms' offerings, particularly those of firms engaging in market-oriented NPD projects, need to be of value to customers and to achieve this a customer must be included in the design. Several strategies for enabling customer co-creation in NPD have been suggested, ranging from allowing users to identify needs in the context of their own uses of the product to engaging with a large and diverse group of potential users to generate a diverse set of NPD ideas for future products or services (Kristensson, Matthing \& Johansson 2008).

From a system mechanism approach, value co-creation has been found to consist of two main principles: firstly, that co- 
creation has a positive impact on the firm's customisation capabilities and secondly that co-creation directly affects the firm's service capability. Also, the firm's service capability influences the firm's customisation capabilities. Results show that capabilities arising from co-creation are different from capabilities arising from an isolated value creation system (Zhang \& Chen 2008).

In a business-to-business context, co-production positively influences service innovation, but this relationship is moderated by the firm's innovation orientation. The degree to which co-production influences service innovation depends on the collaborative firm's expertise, history of business relations, their compatibility with the firm and affective commitment (Chen, Tsou \& Ching 2011).

The design perspective is being applied to the search for innovative organisational structures, business models and strategies. This calls for a co-creation approach: firms must engage and mobilise people across the firm and gather necessary resources to meet the demands of today's customers, who themselves are more engaged and mobilised. Therefore, firms need to learn how to be more responsive and flexible in their responses to customers in order to cocreate value with them; this requires a change in how firms are structured and the strategies they pursue (Leavy 2012).

\section{Negative implications of co-creation for management}

Positive outcomes are not guaranteed if a firm follows a cocreation approach; therefore, there are a number of risks associated with co-creation.

Increased customer participation reduces the control the firm has over the outcome of the value creation process, thereby introducing a higher level of uncertainty and risk (Zhuang 2010). Customers may not exhibit the necessary knowledge and skills to successfully accept the supplier's value proposition and therefore value may not be created. Furthermore, extended legislation may inhibit value cocreation from taking place (Etgar 2008).

Value co-destruction is the process by which value can be destroyed when two parties interact with each other in order to create value. Value can accidentally or intentionally be codestroyed through the interactions between different parties involved in the value creation process, resulting in value destruction through the misuse of resources or by acting in an inappropriate or unexpected manner (Plé \& Cáceres 2010). Value co-destruction has been investigated in the public transport sector providing empirical proof that value can indeed be co-destroyed. Informing, greeting, delivering, charging and helping are five interaction value practices in which value can be either co-created or co-destroyed in the public transport context (Echeverri \& Skalen 2011).

Promoting customer participation in value co-creation has been described as a double-edged sword for firms.
Co-creation results in economic gains for customers and strengthens the customer emotional bond to the firm, but at the same time it increases employees' job stress and hinders their job satisfaction. The value created through the joint collaboration of the customer and the firm depends on the cultural values of customers and employees; therefore, customers and employees should be 'matched' based on their cultural value orientations for successful value co-creation to take place (Chan, Yim \& Lam 2010).

\section{Acknowledgements}

This work is based on research supported in part by the National Research Foundation of South Africa (grant-specific unique reference number 85445).

\section{Competing interests}

I declare that I have no financial or personal relationships that may have inappropriately influenced me in writing this article.

\section{References}

Akaka, M.A. \& Chandler, J.D., 2011, 'Roles as resources: A social roles perspective of change in value networks', Marketing Theory 11(3), 243-260. http://dx.doi. org/10.1177/1470593111408172

Andreu, L., Sanchez, I. \& Mele, C., 2010, 'Value co-creation among retailers and consumers: New insights into the furniture market', Journal of Retailing and Consumer Services 17(4), 241-250. http://dx.doi.org/10.1016/j. jretconser.2010.02.001

Auh, S., Bell, S.J., McLeod, C.S. \& Shih, E., 2007, 'Co-production and customer loyalty in financial services', Journal of Retailing 83(3), 359-370. http://dx.doi. org/10.1016/j.jretai.2007.03.001

Ballantyne, D. \& Varey, R.J., 2006, 'Creating value-in-use through marketing interactions: The exchange logic of relating, communicating, and knowing', Marketing Theory 6(3), 335-348. http://dx.doi.org/10.1177/1470593106066795

Bateson, J.E.G., 1985, 'The self-service customer: An exploratory study', Journal of Retailing 61(3), 49-76.

Bendapudi, N. \& Leone, R.P., 2003, 'Psychological implications of customer participation in co-production', Journal of Marketing 67(1), 14-28. http://dx.doi. org/10.1509/jmkg.67.1.14.18592

Bitner, M.J., Faranda, W.T., Hubbert, A.R. \& Zeithaml, V.A. 1997, 'Customer contributions and roles in service delivery', International Journal of Service Industry Management 8(3), 193-205. http://dx.doi.org/10.1108/09564239710185398

Blazevic, V. \& Lievens, A., 2008, 'Managing innovation through customer coproduced knowledge in electronic services: An exploratory study', Journal of the Academy of Marketing Science 36(1), 138-151. http://dx.doi.org/10.1007/s11747-007-0064-y

Bowers, M.R., Martin, C.L. \& Luker, A. 1990, 'Trading places: Employees as customers, customers as employees', Journal of Services Marketing 4(2), 55-69. http://dx.doi. org/10.1108/EUMO000000002512

Chan, K.W., Yim, C.K.B. \& Lam, S.S.K., 2010, 'Is customer participation in value creation a double-edged sword? Evidence from professional financial services across cultures', Journal of Marketing 74(3), 48-64. http://dx.doi.org/10.1509/ across cultures
jmkg.74.3.48

Chen, J.S., Tsou, H.T. \& Ching, R.K.H., 2011, 'Co-production and its effects on service innovation', Industrial Marketing Management 40(8), 1131-1346. http://dx.doi. org/10.1016/j.indmarman.2011.03.001

Czepiel, J.A. 1990, 'Managing relationships with customers: A differentiation philosophy of marketing', in D.E. Bowen, R.B. Chase \& T.G. Cummings (eds.), Service management effectiveness, pp. 299-323, Jossey-Bass, San Francisco, CA.

Dabholkar, P. 1990, 'How to improve perceived service quality by improving customer participation', in B.J. Dunlap (ed.), Developments in Marketing Science, pp. 483487, Academy of Marketing Science, Cullowhee, NC.

Dong, B., Evans, K.R. \& Zou, S., 2008, 'The effects of customer participation in cocreated service recovery', Journal of the Academy of Marketing Science 36(1) 127-137. http://dx.doi.org/10.1007/s11747-007-0059-8

Echeverri, P. \& Skalen, P., 2011, 'Co-creation and co-destruction: A practice-theory based study of interactive value formation', Marketing Theory 11(3), 351-373. http://dx.doi.org/10.1177/1470593111408181

Edvardsson, B., Tronvoll, B. \& Gruber, T., 2011, 'Expanding understanding of service exchange and value co-creation: A social construction approach', Journal of the Academy of Marketing Science 39(2), 327-339. http://dx.doi.org/10.1007/ s11747-010-0200-y 
Etgar, M., 2008, 'A descriptive model of the customer co-production process', Journal of the Academy of Marketing Science 36(1), 97-108. http://dx.doi.org/10.1007/ s11747-007-0061-1

Firat, A.F., Dholakia, N. \& Venkatesh, A., 1995, 'Marketing in a postmodern world', European Journal of Marketing 29(1), 40-56. http://dx.doi. org/10.1108/03090569510075334

Firat, A.F. \& Venkatesh, A., 1993, 'Postmodernity: The age of marketing', Internationa Journal of Research in Marketing 10(3), 227-249. http://dx.doi.org/10.1016/0167 8116(93)90009-N

Firat, A.F. \& Venkatesh, A., 1995, 'Liberatory postmodernism and the reenchantment of consumption', Journal of Consumer Research 22(3), 239-267. http://dx.doi. org/10.1086/209448

Fitzsimmons, J.A., 1985, 'Consumer participation and productivity in service operations', Interfaces 15(3), 60-67. http://dx.doi.org/10.1287/inte.15.3.60

Füller, J., 2010, 'Refining virtual co-creation from a consumer perspective', California Management Review 52(2), 98-128. http://dx.doi.org/10.1525/cmr.2010.52.2.98

Füller, J., Hutter, K. \& Faullant, R., 2011, 'Why co-creation experience matters? Creative experience and its impact on the quantity and quality of creative
contributions', R\&D Management 41(3), 259-273. http://dx.doi.org/10.1111/ contributions', $R \& D$ Manage
j.1467-9310.2011.00640.x

Goodwin, C., 1988, 'I can do it myself: Training the service consumer to contribute to service productivity', Journal of Services Marketing 2(4), 71-78. http://dx.doi. org/10.1108/eb024745

Grisseman, U.S. \& Stokburger-Sauer, N.E., 2012, 'Customer co-creation of travel services: The role of company support and customer satisfaction with the cocreation performance', Tourism Management 33(6), 1483-1492. http://dx.doi. org/10.1016/j.tourman.2012.02.002

Grönroos, C., 2008, 'Service logic revisited: Who creates value? And who co-creates? European Business Review 20(4), 298-314. http://dx.doi. org/10.1108/09555340810886585

Grönroos, C., 2011, 'Value co-creation in service logic: A critical analysis', Marketing Theory 11(3), 279-301. http://dx.doi.org/10.1177/1470593111408177

Guo, L. \& Ng, I., 2010, 'The co-production of equipment-based services: An interpersonal approach', European Management Journal 29(1), 43-50. http:// dx.doi.org/10.1016/j.emj.2010.08.005

Gurau, C., 2009, 'Marketing flexibility in the context of the service-dominant logic', The Marketing Review 9(3), 185-197. http://dx.doi.org/10.1362/146934709X467758

Kelley, S.W., Donnelly, J.H. Jr \& Skinner, S.J. 1990, 'Customer participation in service production and delivery', Journal of Retailing 66(Fall), 315-335.

Kotler, P. 1986, 'The prosumer movement: A new challenge for marketers', Advances in Consumer Research 13, 510-513.

Kristensson, P., Matthing, J. \& Johansson, N., 2008, 'Key strategies for the successful involvement of customers in the co-creation of new technology-based services', International Journal of Service Industry Management 19(4), 474-491. http:// dx.doi.org/10.1108/09564230810891914

Leavy, B., 2012, 'Collaborative innovation as the new imperative - Design thinking, value co-creation and the power of "pull"', Strategy and Leadership 40(2), 25-34 http://dx.doi.org/10.1108/10878571211209323

Lengnick-Hall, C.A. 1996, 'Customer contributions to quality: A different view of the customer-oriented firm', The Academy of Management Review 21(3), 791-824.

Lovelock, C.H. \& Young, R.F., 1979, 'Look to customers to increase productivity', Harvard Business Review 57(3), 168-178.

McColl-Kennedy, J.R., Vargo, S.L., Dagger, T. \& Sweeney, J.C., 2009, 'Customers as resource integrators: Styles of customer co-creation', viewed 24 June 2012, from
http://www.naplesforumonservice.it/uploads/site files/Meccoll - Customers as http://www.naplesforumonservice.it/uploads/site_files//
Resource Integrators Styles of Customer Co-creation.pdf

Mills, P.K., Chase, R.B. \& Margulies, N., 1983, 'Motivating the client/employee system as a service production strategy', Academy of Management Review 8(2), 301-10.

Mills, P.K. \& Morris, J.H., 1986, 'Clients as 'partial' employees of service organizations: Role development in client participation', Academy of Management Review 11(4), 726-735.

Payne, A.F., Storbacka, K. \& Frow, P., 2008, 'Managing the co-creation of value', Journal of the Academy of Marketing Science 36(1), 83-96. http://dx.doi.org/10.1007/ s11747-007-0070-0
Payne, A., Storbacka, K., Frow, P. \& Knox, S., 2009, 'Co-creating brands: Diagnosing and designing the relationship experience', Journal of Business Research 62(3), 378-389. http://dx.doi.org/10.1016/j.jbusres.2008.05.013

Plé, L. \& Cáceres, R.C., 2010, 'Not always co-creation: Introducing interactional codestruction of value in service-dominant logic', Journal of Services Marketing 24(6), 430-437. http://dx.doi.org/10.1108/08876041011072546

Potts, J., Hartley, J., Banks, J., Burgess, J., Cobcroft, R., Cunningham, S. et al., 2008, 'Consumer co-creation and situated creativity', Industry and Innovation 15(5), 549-474. http://dx.doi.org/10.1080/13662710802373783

Prahalad, C.K. \& Ramaswamy, V., 2000, 'Co-opting customer competence', Harvard Business Review 78 (January-February), 79-87.

Prahalad, C.K. \& Ramaswamy, V., 2003, 'The new frontier of experience innovation', MIT Sloan Management Review 44(4), 12-18. Prettiness

Prahalad, C.K. \& Ramaswamy, V., 2004, 'Co-creation experiences: The next practice in value creation', Journal of Interactive Marketing 18(3), 5-14. http://dx.doi. org/10.1002/dir.20015

Ramaswamy, V., 2008, 'Co-creating value through customers' experiences: The Nike case' Strategy and Leadership 36(5), 9-14. http://dx.doi. org/10.1108/10878570810902068

Ramaswamy, V., 2009, 'Leading the transformation to co-creation of value', Strategy and Leadership 37(2), 32-37. http://dx.doi.org/10.1108/10878570910941208

Ramaswamy, R. \& Gouillart, F., 2010, 'Building the co-creative enterprise', viewed 03 March 2011, from http://www.gsg.com.au/media/24460/r1010j-pdf-eng.pdf

Randall, W.S., Gravier, M.J. \& Prybutok, V.R., 2011, 'Connection, trust, and commitment: Dimensions of co-creation?', Journal of Strategic Marketing 19(1), 3-24. http://dx.doi.org/10.1080/0965254X.2010.537760

Roggeveen, A.L., Tsiros, M. \& Grewal, D., 2011, 'Understanding the co-creation effect: When does collaborating with customers provide a lift to service recovery?', Journal of the Academy of Marketing Science 40(6), 771-790. http://dx.doi. $\mathrm{org} / 10.1007 / \mathrm{s} 11747-011-0274-1$

Rowley, J., Kupiec-Teahan, B. \& Leeming, E., 2007, 'Customer community and cocreation: A case study', Marketing Intelligence and Planning 25(2), 136-146. http://dx.doi.org/10.1108/02634500710737924

Terblanche, N.S., 2005, 'A century of marketing: Achievements, mishaps and future challenges', Management Dynamics 14(4), 2-17.

Toffler, A., 1980, The Third Wave, Bantam Books, New York, NY.

Van Raaij, W.F. \& Pruyn, A.T.H., 1998, 'Customer control and evaluation of service validity and reliability', Psychology \& Marketing 15(8), 811-832. http://dx.doi. org/10.1002/(SICI)1520-6793(199812)15:8<811::AID-MAR6>3.0.CO;2-8

Vargo, S.L. \& Lusch, R.F., 2004, 'Evolving to a new dominant logic for marketing', Journal of Marketing 68(1), 1-17. http://dx.doi.org/10.1509/jmkg.68.1.1.24036

Vargo, S.L. \& Lusch, R.F., 2008, 'Service-dominant logic: Continuing the evolution', Journal of the Academy of Marketing Science 36(1), 1-10. http://dx.doi. org/10.1007/s11747-007-0069-6

Vargo, S.L., Maglio, P.P. \& Akaka, M.A., 2008, 'On value and value co-creation: A service systems and service logic perspective', European Management Journal 26(3), 154-152. http://dx.doi.org/10.1016/j.emj.2008.04.003

Wind, J. \& Rangaswamy, A., 2000, Customerization: The next revolution in mass customization, report 2000-108, Marketing Science Institute, Boston, MA.

Xie, C., Bagozzi, R.P. \& Troye, S.V., 2008, 'Trying to prosume: Toward a theory of consumers as co-creators of value', Journal of the Academy of Marketing Science 36(1), 109-122. http://dx.doi.org/10.1007/s11747-007-0060-2

Yi, Y. \& Gong, T., 2012, 'Customer value co-creation behavior: Scale development and validation', Journal of Business Research, in press (please confirm if in press, or provide with page numbers).

Zhang, X. \& Chen, R., 2008, 'Examining the mechanism of the value co-creation with customers', International Journal of Production Economics 116(2), 242-250. http://dx.doi.org/10.1016/j.ijpe.2008.09.004

Zhuang, W., 2010, 'Balancing customer and marketing inputs to maximize the value experience', PhD thesis, Department of Marketing and Analysis, Louisiana Tech University.

Zwick, D., Bonsu, S.K. \& Darmody, A., 2008, 'Putting consumers to work: "Co-creation" and new marketing govern-mentality', Journal of Consumer Culture 8(2), 163196. http://dx.doi.org/10.1177/1469540508090089 